\title{
Iran's Political Stance toward Yemen's Ansar Allah Movement: A Constructivist-Based Study
}

\author{
Keyhan Barzegar ${ }^{1} \&$ Seyyed Morteza Kazemi Dinan ${ }^{1}$ \\ ${ }^{1}$ Department of Political Science and International Relations, Faculty of Law and Political Science, Science and \\ Research Branch, Islamic Azad University, Tehran, Iran \\ Correspondence: Keyhan Barzegar, Department of Political Science and International Relations, Faculty of Law \\ and Political Science, Science and Research Branch, Islamic Azad University, Tehran, Iran. E-mail: \\ kbarzegar@hotmail.com
}

Received: July 13, 2016 Accepted: August 4, 2016 Online Published: October 30, 2016

doi:10.5539/jpl.v9n9p77 URL: http://dx.doi.org/10.5539/jpl.v9n9p77

\begin{abstract}
In recent years, the role of non-state political groups, particularly in the Middle East has become more prominent. Islamic Republic of Iran has to have a policy toward such groups. One of these groups is Yemen's Ansar Allah who, after the outbreak of protests in the country since 2011, has had a high and effective role in the political arena of Yemen. In this study, based on Constructivist theory of international relations, we attempted to answer this fundamental question that "what is the strategy of Islamic Republic of Iran toward Yemen's Ansar Allah?" Islamic Republic of Iran with regard to the definition of their identity and perceptions of the structure of the international system and the behavior of important regional and international actors as well as their opinions about Ansar Allah Movement as a Shiite, popular, anti-Israel, anti-American, and anti- Saudi group aligned with the values and principles of Islamic Republic System, has taken a supportive stance. Iran's support for Yemen's Ansar Allah is political, diplomatic, media and if possible, material supports (e.g. sending foods and medicine).
\end{abstract}

Keywords: Ansar Allah movement, Houthis, Yemen, Islamic Republic of Iran, strategy, constructivism

\section{Introduction}

New in international relations, we are seeing an increase in the relative position of non-state political actors in international relations. These actors in recent years, have had undeniable and prominent roles and impacts. Therefore, we can not identify and assess the foreign policy of a country only based on state-centric foreign relations. In the Middle East, according to political developments in Arabic countries from 2010 to the present, political, non-state and Islamist actors (such as Ansar Allah in Yemen, Al-Wefaq in Bahrain and the Muslim Brotherhood in Egypt) have contributed effectively in the political arena of their countries as well at the regional level, such that in some areas they have changed the head of state (e.g. in Yemen) or have had an impact on the relations between two or several Middle Eastern countries (Iran-Saudi Arabia, Egypt-Saudi Arabia, Iran-Bahrain, Iran-Yemen, Iran-Turkey, etc.).

With regard to this case, it is clear that one of important issues in study of a country's foreign policy is the type of approach to the non-state political players; an approach that should be taken very professional and realistic. The important point to policy makers is that on the world stage you can not reach the realization of national goals and strategies with slogans and show. Foreign policy must be managed based on current realities. In this regard, Iran as one of the most important and powerful players in the Middle East, to realize their aims, should has a policy based on precise and rational calculations connected with the other actors in the region including actors such as Yemen's Ansar Allah. In this paper we aim to study this policy and strategy of Iran toward this group based on theory of constructivism.

\subsection{Theory of Constructivism}

Constructivism is an international relations theory that believes that states exist within a world of our own making, and that they are social rather than material. It "emphasizes the social construction of world affairs as opposed to the claim of (neo)realists that international politics is shaped by the rational-choice behaviour/decisions of egoist actors who pursue their interests by making utilitarian calculations to maximize their benefits and minimize their losses, hence the materiality of international structures" (Behravesh, 2011). 
Giambattista Vico, Neapolitan philosopher (1668-1744), considered the first precursor of constructivism. Leading constructivist scholars are: Friedrich Kratochwil (1989), Nicholas Onuf (1989),Alexander Wendt (1992), and John G. Ruggie (1998). According to constructivists, social world is not something "out there"; it only exists as an intersubjective awareness and is meaningful for those who have made it. In this regard, the system is composed by ideas not material forces. If the ideas change, the system will change as well; that is why Wendt (1992) repeated a phrase that: "anarchy is what states make of it" (cited by Jackson and Sorenson, 2012, p. 162). Constructivists emphasize on the role of "ideas" and "common understanding of the social world". For example, UK's 500 nuclear weapons are less dangerous to US than North Korea's five nuclear weapons, because UK is a friend of US, but North Korea is not; friendly and hostile relations are the results of common understanding. Similar to Critical and postmodern theorists, constructivists believe that external and objective social reality as it may seem, does not exist. The key idea is that the social world including international relations is a human structure. According to Wendt (1994), Constructivism is a structural theory of the international system that makes the following core claims: (1) states are the principal units of analysis for international political theory; (2) the key structures in the states system are intersubjective rather than material; and (3) state identities and interests are in important part constructed by these social structures, rather than given exogenously to the system by human nature (as neorealists maintain) or domestic politics (as neoliberals favour).

\section{Ansar Allah Movement}

Currently, Hizb al-Haqq and Ansar Allah (Houthis) are two major groups of Shiite in Yemen. Hizb al-Haqq is a Zaydi religious party formed after the unification between North and South Yemen in 1990, and its founders are some of the prominent Zaydi scholars and judges. After the end of Yemeni civil war in 1994, the activities of this party were plunged into the abyss such that the group al-Shabab al-Momen (current Ansar Allah Movement) was formed from it (Rajeh, 2013). Some researchers believe that Houthi movement is a radical interpretation of Zaidi sect in the form of Houthi ideas, and to revive the Zaydi identity which was formed in response to the spread of Wahhabism ideas in Yemen, and began as a movement or an intellectual, political and an armed organization for the first time in 1991. The most important demands of Houthis include: The same development across the country (health, cultural, etc.), permission to freely teach their views in their schools, and permission to carry out their actions and intrusion prevention of Wahhabis (Gharibreza \& Tahami, 2010). Fernando Carvajal, a former Yemen-based NGO consultant, told VICE News that the priority of the Houthis is to upset the political-military order in north Yemen. By delegitimising the government and pushing for populist ideals, the Houthis, offer themselves as an alternative government in an effort to attract more numbers to their group (de Haan, 2014, p. 2).

Ansar Allah Movement presented itself as an Anti-American group since 2002 and they publicly raised the chants of "Allahu akbar, Death to America, death to Israel, curse upon the Jews, victory to Islam" in mosques and ceremonies (Talashan, 2012). This group made political actions until 2004, and even some of its members such as Hussein al-Houthi participated in the parliamentary elections in 1993 and 1997, and was elected to Parliament in Yemen. Gradually with increasing pressure and military invasion of the central government, the Houthis entered into military and armed phase, and made six war with government(from 2004 to 2009); in the sixth war, the Saudi Air Force officially came to help the Yemeni army and suppressed the Houthis. After the martyrdom of Seyyed Hussein al-Houthi, leader of Ansar Allah movement in 2004 in the war against the regime of Ali Abdullah Saleh, his youngest brother, Sayyed Abdul Malik al-Houthi took the reins of leadership who has high management power and high political wisdom. Asadi (2014) believes that the reasons for power of the Houthis in Yemen in recent years are: Yemen state bankruptcy as a result of inappropriate policies of Abdullah Saleh, poverty $(54.5 \%)$ and unemployment $(60 \%)$.

\section{Iranian Involvement in Yemen}

The Yemeni government has always accused Iran of supporting (especially military support) Houthi Shiite fighters. Of course, we can not deny the influence of Iran's Islamic Revolution and its values and principle on Ansar Allah Shiite movement, but Iran has denied any involvement. A US envoy to Yemen, Gerald Feierstein, also accused Iran of supporting secessionists in Yemen's south at the time. According to de Haan (2014), although there is no conclusive evidence of Iranian support for the Houthis, involvement in Yemen by regional rivals, Iran and Saudi Arabia, is nothing new. Some analysts, therefore, see Yemen as a proxy war battleground between Saudi Arabia and Iran, with the Houthis fighting on behalf of Iran (Ibid., p. 3). Bernard Haykel, a professor at Princeton University, stating that Iranian support for the Houthi rebel group is simply opportunistic, believes that "Iranians want to needle the Saudis in every possible way... But to say that the Houthis are proxies of Iran is stretching the boundaries of credibility" (Ibid., p. 3).

Gregory Gause, in a report published by Brookings Doha Center in 2014 stated that: "The Houthis adopted much 
of the rhetoric of the Iranian regime, including bombastic anti-American and anti-Israeli language" (Gause, 2014, p.14). Also, he wrote that Riyadh launched a major military operation against Yemen to win against Tehran in the regional contest for influence. In a International Crisis Group Report published in 2014 titled The Huthis: From Saada to Sanaa, it was stated that: "Huthi representatives maintain they are Zaydi, not Twelver, but the group's political sympathies with Tehran, its slogans, its celebration of Ashura and allegations of material support from Iran and Hizbollah are raising doubts about their true loyalties" (p.10). This report wrote that the Huthis are "hidden Iranian agenda" (p.13). A spokesman for Yemen's Shiite Ansar Allah movement, Mohammad Abdul-Salam, hailed Iran's stance on the recent developments in the Arab country as "positive", saying that the Islamic Republic has supported the Yemeni nation. He further rejected the claim that Tehran has interfered in Yemen's internal affairs by providing support for the September 21 Revolution: "Those who raise such allegations (against Iran) intend to downplay the Yemeni nation's role in the revolution". (Tasnim News Agency, 2015)

\section{Iran's Political Stance toward Ansar Allah Movement}

First, it is important to note that the increase in Iran's regional role is linked to the needs of Shiite in acceptance of the role and political, financial and logistical support of Iran at the regional level. the need for Iran's role becomes more obvious with the continued presence of US and possible changes of their policies in Iraq in favor of the Sunni groups and their long-term threat from one hand, and sabotage of traditional Arab regimes such as Saudi Arabia and Egypt in full acceptance of Shiite groups in the new order of Iraq on the other hand. In other words, Shiites who have been away from making power for many years, with forming the first Shiite government in Arab world, need the support of the only friend in region, Iran. In this section we discuss about Iran's stance on Houthi movement in Yemen from the view of the leader and senior politicians, diplomatic apparatus, and media.

\subsection{Leader and Senior Politicians}

Islamic Republic of Iran as a Shiite Islamic state with Islamic ideology, claim the leadership of the Shia world and in its upstream documents and the constitution there is also special emphasis on the need to support the liberation movements and protests of oppressed nations including Shia and non-Shia and even non-Muslim. Article 154 of Iran's Constitution says:

"The Islamic Republic of Iran has as its ideal human felicity throughout human society, and considers the attainment of independence, freedom, and rule of justice and truth to be the right of all people of the world. Accordingly, while scrupulously refraining from all forms of interference in the internal affairs of other nations, it supports the just struggles of the mustad'afun against the mustakbirun in every corner of the globe".

In this regard, Ayatollah Ali Khamenei, the leader of Iran, has also supported protests of Yemeni people (led by Ansar Allah) in different periods. His statements in likening the invasion of Saudi Arabia to Yemen to the Israeli crimes in Palestine is one of them. He also in his meeting with the president of Iraq on May 13, 2015, while strongly condemned the Saudi invasion of Yemen, called on Riyadh to stop killing Yemeni people immediately, and added: Yemen incidents show that a non-wise and ignorant thinking makes decisions on Yemen issues within the Saudis... They invaded Yemen on the pretext of Yemen's resigned and fugitive President who had betrayed his country in the most critical conditions.

Hassan Rouhani, Iran's president on Iranian TV channel 1, in May 2015 took serious stance, and considered the failure of Saudi Arabia in different regions as the reason for their invasion to Yemen, and emphasized the need to condemn this attack.: A country (Saudi Arabia) has had some ambitions; being unsuccessful in Iraq, in Syria, in Lebanon, in North African countries, now this all failures have accumulated, caused the intellectual and spiritual imbalance of that country, and turned into a bomb dropping on people. The world should condemn this aggression, categorically. The destiny of every country is in the hands of its people. Ali Larijani, the speaker of parliament, in an open session of parliament on May 13, 2015 gave a speech condemning Saudi attack to Yemen: Our support for the Yemeni people is an Islamic support... Saudis claim that Iran's spiritual influence and military power threaten them. Why do you have such a miscalculation? Even today, with all hostility you have had to Yemeni people, if Israel attacks you, Iran will defend you because your nation is Muslim...Now, Saudi Arabia should have an accurate assessment of their behavior; these actions not only are not good for their security, but also utterly destroy their Islamic reputation. Admiral Ali Shamkhani, secretary of the Supreme National Security Council in Iranian TV channel 1 (May 30, 2015) took a stand about developments in Yemen: Today a small group (Ansar Allah movement) who had no claim to rule in Yemen, is a global group. We can not ignore the fate of the Muslim world; we commiserate with the oppressed of the world. 
Iran's explicit support of the Ansar Allah, is not limited to political and diplomatic officials, and senior Iranian military commander in this area have also several stances. Mohammad Ali Jafari, commander of Iranian Revolutionary Guards, speaking at a anti-US meeting at Tehran University after nuclear deal (November 2, 2015) said: We do all that we can do in relation to Yemen. There is a need for a country as a supporter for Yemen to help them well... Travel of Ansar Allah to south had a bonus that enemies thought they had won but in fact, it was like a 20-percent enrichment strategy and our negotiations.

General Hossein Salami, deputy commander of the Iranian Revolutionary Guards in a program on Iranian TV (April 18, 2015) denied Iran military presence in Yemen. He pointed to the strength and power of the Yemeni people and Ansar Allah and said: Ansar Allah and the Army and the people of Yemen have unified, and have shaped a large area of deep resistance... We support them strongly. We give them political support, spiritual support, and even humanitarian support. We provide food and medicine for them. If the path be open, we do not hesitate to send any help.

\subsection{Diplomatic Apparatus}

From the beginning of uprisings and unrest in Yemen in 2011, So far, Iran's diplomacy apparatus has adopted serious stance in support of the demands of protesters, especially Ansar Allah (as the leader of protesters). Major diplomatic stance of Iran in this regard has been taken by former Deputy Foreign Minister for Arab and African Affairs, Hossein Amir-Abdollahian. He, in a News conference in Cairo (January 2013) said: Iran's stance toward Bahrain, Yemen and Syria is similar and its basis is land its base is lack of foreign intervention and domestic dialogue for reform.

After the escalation of military and aerial attacks of Saudi Arabia to Yemen, he said: These measures are conducted only to strengthen terrorists and the Israeli regime. Iran will not allow others to manipulate regional security with their adventurous actions. Amir-Abdollahian in an interview with IRIB News Agency (May 19, 2015) emphasized that the measure of Saudis to hold meeting in Riyadh for the Yemen issue as a gesture to reduce international pressure and public opinion. Haste of Saudi Arabia and movement ahead of the UN not only does not help to resolve Yemen's problems, but also it will cause a delay in political process and measures of the UN organization... Saudi Arabia, in invasion to the defenseless and oppressed people of Yemen uses exactly the same behavior and criminal pattern of Zionist regime in Gaza .

Mohammad Javad Zarif, Iran's foreign minister in a letter to UN Secretary-General in April , 2015, condemning the aggression of Saudi Arabia to Yemen and emphasizing the non-intervention in this country, proposed a 4-point plan to resolve the crisis in Yemen. It included a cease-fire, humanitarian assistance, a dialogue among local factions, and an agreement by regional and other powers that the country should have "a broad-based government friendly to all its neighbors (Román, 2015). According to this plan it becomes clear that Iran is opposed to the disarmament of Ansar Allah and at the same time emphasizes the participation of all groups including Ansar Allah in dialogue to solve the crisis in Yemen. Marzieh Afkham, former Foreign Ministry spokesman also said: The solution for Yemen solution is a political solution, not a military solution. Iran takes any action for its political progress. The Yemeni peace talks Should take shape (IRINN, 23 April 2015)

\subsection{Media}

The Islamic Republic of Iran, along with using its diplomatic capacities to warn the rulers of Yemen to respect the rights of protesters, has tried and will try to, with the use of its regional and international media arms including Press TV and Al-Alam, highlight the protests in Yemen and Ansar Allah leaders' stances. For example, in a research it was found out that that In a 6-month period (from April to September 2015), in 90 percent of the time, the networks of Al-Alam and Press TV, everyday had released at least one or two of news and analytical reports about Yemen and the stances of Ansar Allah, especially Sayed Abdul Malik Houthi. Also they had broadcast live or recorded interviews with some officials and activists of this group such as Abdul Rahman Mokhtar representative of Ansar Allah in Yemen's national unity dialogues, and Muhammad al-Bakhit, political committee member of Ansar Allah (Kazemi Dinan, 2015).

With formal complaints of Iranian officials, Islamic Republic of Iran Broadcasting (IRIB) television networks, especially Press TV and Al-Alam, and International News Network (IRINN) as well as State news agencies and newspapers such as Al-Wefaq, Arabic Kayhan, IRNA, ISNA, Tasnim, Fars News, Kayhan, Iran, Jame Jam, and Resalat at the same time gave extensive coverage of the event and highlighting the protests in Yemen. On April 23, 2015, a documentary program, "Aqeeq Heart" was broadcast from IRIB Channel 1, where by studying and analyzing developments in Yemen and criticizing the previous governors of Yemen as well as the US and the West (because of their support for the regime of Ali Abdullah Saleh) gave full support of the protesters in Yemen and in particular, the popular committees and Ansar Allah. On April 24, 215, The SEVEN program of IRIB 
channel 3, by inviting Dr. Ghazanfar Rokn Abadi (former Iranian ambassador to Lebanon), analyzed the causes of Saudi Arabia aggression to Yemen, and explicitly supported the actions of Ansar Allah movement. The speech of Seyyed Hassan Nasrallah, Hizbullah Secretary General, about developments in Yemen was broadcast live on IRINN (May 5, 2015) which implied a strong support of the Ansar Allah movement and the popular committees, and strong condemnation of Saudi aggression to Yemen. This news network also showed large and prominent anti-Saudi protests of Yemenis who had been invited by Ansar Allah movement (May 18, 2015). IRINN also broadcast a documentary program named "Yemen" for the support of Ansar Allah movement and sharp criticism of Saudi Arabia and Abd Rabbuh Mansur Hadi, Yemen's fugitive former President (June 16, 2015). IRINN also sometimes broadcast some reports and photos related to Al-Masirah TV (Media arm of Ansar Allah movement). Fars news agency which is one of the most important Iranian news agencies, from the beginning of the unrest in Yemen, has constantly reported the developments in this country, and in its analyses presented in this context have stressed the support for the Ansar Allah movement. Such that at sometimes, even considered Ansar Allah' retreat from some areas, especially in southern, as a tactical action (Fars News Agency, 31 August 2015). Emphasis on resistance of people, especially Ansar Allah movement, condemning Saudi bombing of Yemen, frequent airing of Supreme Leader's excerpts about Saudi aggression to Yemen, Emphasizing the need for rapid and peaceful settlement of the crisis in Yemen, and criticism of Mansur Hadi are those set forth in Iranian state media about Yemen and Ansar Allah. In a research it was reported that $32.1 \%$ of news reported in major Iranian newspapers is about Yemen (Mohammadizadeh \& Asadi, 2013). With this Media and communicative approach, we can see that Iran seeks to make maximum use of components of soft power to influence events in Yemen in particular and regional equations in general (Tuti \& Doost Mohammadi, 2013).

\section{Conclusion}

Given Iran's stances on Ansar Allah movement from the perspective of its senior politicians, diplomatic apparatus, and media, and based on constructivism theory, It seems that Islamic Republic of Iran, based on an identity that has defined for itself (Muslim, Shia, anti-oppression, anti-Israel) and Saudi Arabian regimes and governments of Ali Abdullah Saleh and Mansour Hadi (unpopular, corrupt, despotic, tyrannical, and aligned with America and Israel) as well as their opinions about Arabic developments in the last four years and the current structure of the international system , consider Yemen as an example of the Islamic Awakening, and on this basis, plans its foreign policy towards these developments and the largest and most influential group of protesters, the Ansar Allah movement. In other words, the Islamic Republic of Iran based on its proposed and fundamental principles and values such as fighting oppression, countering the spread of US and Israeli influence and power in the region, countering the spread of takfiri ideology in the Muslim world, and supporting Shiites in the region and the world, supports the popular protests in Yemen, and strengthen the Ansar Allah. It is obvious that this kind of behavior has arisen from a mental structure formed in the Islamic Republic system and its approach to regional developments. In this context, in addition to the traditional methods of diplomacy, and official comment by the Minister, the Foreign Ministry spokesman, etc., Iran will take full advantage of the tools of soft power i.e. using his ubiquitous media to support the Yemeni protesters, especially Ansar Allah.

The study results showed that currently, the use of hardware methods such as equipment and armaments or military training members of Ansar Allah movement do not matter, and probably it also will not have effective result and vice versa, it will cause heavy costs to the Islamic Republic and Yemeni protesters, and may double the pressures on them. In other words, it seems now, adhering to the methods of soft power and public diplomacy, is Iran's basic strategy toward Yemen's Ansar Allah, and in the current situation in the region, Iran knows that this is the most effective method of dealing with Yemen. This orientation is based on intersubjective structure and identity that Iran has defined for US and its allies in the region, and has come to the conclusion that if they enter the field of hardware to support Shiites in Yemen, with increasing sensitivity, it not only increases pressure on them, but also this will become a serious Achilles heel for the Islamic Republic in the region and will finally be to the detriment of the national interests of the Islamic Republic of Iran.

In practice, it can be seen that Iran is very careful and sensitive to enter any direct confrontation with the US in Iraq and the Persian Gulf region. Meanwhile, in conjunction with other key players in the region such as Saudi Arabia and Egypt, the Islamic Republic of Iran is trying to maintain and develop friendly relations through expanding cooperation and security guarantees. For this reason, as much as possible, Iran is trying to maintain a balance between supporting the Islamist non-state groups like Ansar Allah movement and its relations with Saudi Arabia. It reveals a serious impact of regional power-sharing structure on agency like Iran. In contrast, Saudi behavior towards Yemen and Ansar Allah movement which changed from political and indirect situation to direct and military aggression, is to suppress and completely eradicate Ansar Allah, and thus increase the relative safety and maintain dignity, prestige and position in the region and counter Iran's rising influence in the region. Despite 
the fact that Iran's stance towards the people of Yemen and Ansar Allah is in order to realize their demands, and is limited only to the political and spiritual support, but Saudi interprets it as aggressive behavior. This interpretation of Saudi Arabia is based on the structure formed in the minds of the leaders of Saudi Arabia about Iran and Shiites in the region that implies the components of constructivism theory.

\section{References}

Asadi, A. A. (2014). Bohrane Yemen: Az do paregi siasi ta reghabathaye mantaghei [Yemen crisis: form political fragmentation to regional competitions]. Tehran: Strategic Research Center of the Expediency Council. ( In Persian)

Behravesh, M. (2011, February 3). Constructivism: An Introduction. E-International Relations. Retrieved from http://www.e-ir.info/2011/02/03/constructivism-an-introduction/

de Haan, J. (2014, November 11).Yemen; factors behind possible economic and political collapse. Strategic analysis paper, Future Directions international. Retrieved from http://apo.org.au/resource/yemen-factors-behind-possible-economic-and-political-collapse

Fars News Agency, (2015, August 31). Vaziate meydanie yemen: Joghrafiyaye chiregi va bartarie nezami [field situation of Yemen: Geography of dominance and military superiority]. (Text in Persian). Retrieved from http://www.farsnews.com/newstext.php?nn=13940608001357

Gause, G. (2014, July 22). Beyond Sectarianism: new Middle East cold War. Brookings Doha Center Analysis paper. No .11, Retrieved from http://www.brookings.edu/research/papers/2014/07/22-beyond-sectarianism-cold-war-gause

Gharibreza, H. R., \& Tahami, A. R. (2010). Jaryanshenasie Mantagheye Khavarmiane: Tashyi siasi dar mantaghe [The trend of the Middle East: Political Shi'ism in the region]. Zamane, 91 and 92, 70-72. (In Persian)

International Crisis Group. (2014, June 10). The Huthis: From Saada to Sanaa. Middle East Report, no. 15. Retrieved from http://www.crisisgroup.org/en/regions/middle-east-north-africa/iraq-iran-gulf/yemen/154-the-huthis-from-sa ada-to-sanaa.aspx

Jackson, R., \& Sorenson, G. (2012). Introduction to International Relations. Theories and Approaches (4th ed.). Oxford: Oxford University Press.

Kazemi Dinan, S. M. (2015). Arzyabie nahveye etelaresanie tahavolate yemen dar shabakehaye Al-Alam and Press TV [Informing assessment of Yemen developments in Al-Alam and Press TV networks]. Tehran: Monitoring and Evaluation Department of radio and television news and political programs. (In Persian)

Kratochwil, F. V. (1989). Rules, norms, and decisions: On the conditions of practical and legal reasoning in international relations and domestic affairs. Cambridge, Cambridgeshire: Cambridge University Press. http://dx.doi.org/10.1017/CBO9780511559044

Mohammadizadeh, F., \& Asadi, A. ( 2013). Nahveye baztabe tahavolate Bahrain, Yemen va Syria dar Matboate Iran [reflection of developments in Bahrain, Yemen and Syria in Iranian press]. Islamic Revolution Studies, $10(33), 303-322$

Onuf, N. G. (1989). World of Our Making. Columbia: University of South California Press.

Rajeh, A. R. (2013). Jonbeshhaye eslamie Yemen [Islamic movements in Yemen]. In M. R. Hatami, \& M. Bohrani (Eds.), Dayeratolma'arefe jonbeshhaye eslami [Encyclopedia of Islamic movements] Tehran: Institute of Social and Cultural Studies. (In Persian)

Román, D. (2015, April 14). Iran Says it Doesn't Want to Dominate Yemen. Retrieved from http://www.wsj.com/articles/iran-foreign-minister-javad-zarif-puts-forward-peace-plan-for-yemen-1429006 525

Ruggie, J. G. (1998). What Makes the World Hang Together? Neo-utilitarianism and the Social Constructivist Challenge. International Organization (CUP), 52(4), 855. http://dx.doi.org/10.1162/002081898550770

Talashan, H. (2012). Enghelabe eslamie Iran va tasire an bar tahavolate jeopolitike shi'e dar Yemen [Iran's Islamic revolution, and its impact on geopolitical changes of Shiites in Yemen]. Shia studies, 10(40), 7-30. (In Persian)

Tasnim News Agency. (2015, March 11). Ansarullah lauds Iran's supports for Yemeni nation. Retrieved from http://theiranproject.com/blog/2015/03/11/ansarullah-lauds-irans-supports-for-yemeni-nation/ 
Tuti, H., \& Doost Mohammadi, A. (2013). Tahavolate enghelabie Bahrain va barrasie rahbordhaye siasate kharejie Iran dar ghebale an [The revolutionary developments in Bahrain, and Iran's foreign policy strategies toward it]. Islamic Revolution Studies, 10(33), 209-226.

Wendt, A. (1992). Anarchy is What States Make of It: The Social Construction of Power Politics. International Organization, 46(2), 410. http://dx.doi.org/10.1017/S0020818300027764

Wendt, A. (1994). Collective Identity Formation and the International State. American Political Science Review, 88(2), 384-396. http://dx.doi.org/10.2307/2944711

\section{Copyrights}

Copyright for this article is retained by the author(s), with first publication rights granted to the journal.

This is an open-access article distributed under the terms and conditions of the Creative Commons Attribution license (http://creativecommons.org/licenses/by/4.0/). 